\title{
Internal and External Factors Influencing Financial Performance in Improving Competitiveness of Small and Medium Enterprises in Jayapura City
}

\author{
Mugiati \\ University of Science and Technology Jayapura, Indonesia \\ a.mugiati@yahoo.com
}

\begin{abstract}
This study aims to identify and analyze the direct influence of internal factors (consisting of: Human Resource Management, Production, Marketing, Working Capital, Organization) and External Factors (which are Government Policy and competitors) on Financial Performance of Small and Medium Enterprises in Jayapura city. Data collecting method data are observation, interviews, and questionnaire. Data were analyzed using analysis of SEM (Structural Equation Modeling), with Amos Software. Results show that internal factor like human resource management does not affect the financial performance of Small and Medium Enterprises in Jayapura city, while the internal factors of production, marketing, working capital, organizational influence the financial performance of Small and Medium Enterprises in Jayapura city. The analysis also showed that the internal factors of human resource management, production, marketing, working capital and organizational influence on the competitiveness of Small and Medium Enterprises in the city of Jayapura. External factors which consist of: government policies and competitors affect the financial performance and competitiveness of small and medium enterprises businesses in the city of Jayapura. Financial performance affects the competitiveness of Small and Medium Enterprises in Jayapura city.
\end{abstract}

Keyword: Financial Performance, Factor Internal, External Factors, Power Competitiveness, Small and Medium Enterprises

\section{Introduction}

Economists argue that the small business sector has a durability that has been tested on a variety of economic conditions and able to withstand the various conditions of the competition with great effort (Sasono, 2002: 157). The reality has shown that most of the small business sector has not received serious attention for example, has not received capital assistance, although with a relatively small capital itself. With great effort made by the actual owner of the production process can still run, only thus relatively slow progress due to various limitations associated with management factors, capital and technology. Tambunan (2002: 19) also mentions that the performance of Small and Medium Enterprises in Indonesia is still low. This is due to the weakness of management, marketing, capital, technology and human resources are owned by small businesses. While some opinion states that the factors causing the lack of success of small businesses is the inability of management, weaknesses in decision making, inexperienced, weak financial supervision and weak in marketing (Scarborough et al., 1993: 38). In a state that is growing, small businesses need to be supported by a number of funds and financial resources as needed. Conversely, when the business is not yet in need of funds, because the business turnover is low, then the capital provided should be less. If the business turnover is high, capital should be sufficient to meet the needs of the business or there must be agreement in strategic financial decisions. The existence of conformity on these aspects requires a financial planning or business skill levels are quite focused.

In addition, the course of business through which small companies has not separated from the policies and programs of government aid. But the Government's policy has indirectly resulted in conditions that encourage growing larger. This can be evidenced by the many large companies who do affiliate with small businesses, especially small industrial goods so that small businesses can move more efficiently. In the current competitive situation like this, an entrepreneur must be able to formulate internal strengths in business strategy by performing a combination of opportunities and threats external environment. Until now this appears to conditions in small firms still have weaknesses in determining strategic and tactical business (Stifung, 1991: 88). With the rapid economic growth and current business developments, as well as the 
situation of the opening of the free market. With the increasing number of goods on offer and the increasingly intense competition, sued the company more innovative in improving the management and policies of production and financial structure, than the government took measures to open up opportunities for businesses in certain circumstances it can also be an opportunity or instead can be a threat to small companies.

Research directed at small businesses will always be relevant, because the construction sector has been focused on areas with a populist economic linkage between industry and agriculture. The main priorities were developed among others by structuring the industry that lead to the strengthening and deepening the industrial structure that is supported by high-tech capabilities. Industrial development should be improved in order to become a major driver of economic efficiency and high competitiveness. Such companies will have a more solid structure with evolving patterns of production, of goods which rely on productive labor and abundant natural resources, into quality goods of high added value and have a competitive advantage. Seeing the importance of small businesses assess this, it is necessary to know the level of performance of the company through strategic perspective approach. By knowing the level of performance of the company, it can be used as a guide for those who will participate in supporting small businesses. This can be seen the internal capability of each group company and the magnitude of the role of aid that has been given (by the condition of each internal-owned), so that it can be seen picture of internal factors and external What are the most dominant in the handling of small business development, especially in the city of Jayapura.

\section{Literature Review}

Collis and Montgomery in a journal entitled "Competing in the Resources Strategy Era of the 90s" with a report titled: "How do you create and maintain a profitable strategy", they concluded that: Towards the end of the 90s, several large companies have to struggling to maintain their existence Resource Based View Of The Firm (RBV) combines the company's internal analysis by external analysis of the industry and competitive environment. KBV be identifies on technology management. Dengfan approach to RBV, the company will be able to identify objectively determinant in keuanggulan competing. The similarities with the research by the authors are equally related to the quality and competitiveness. Satyagraha in a report of his research entitled: "Competitive Advantage and Redefinition SWOT," he concludes that: "The quality of human resources of competitive advantage, has two privilege, (1) special skills - skills) and (2) special resources (superior resources). Kwon and Shin (2003) examines About Cointegration and Causality between Macroeconomic Variables and Stock Market Return. The results showed the capital market in Korea reflects the macroeconomic variables such as the production index, exchange rate, trade balance and the money supply. Pakpahan argues, written by Daulay, Hotmatua and Mulyanto (2001: 80), defines competitiveness as measured by dalah competitive production costs. The lower the production cost per unit of a product that is said to be competitive against products produced. A society is said to pick the high competitiveness if it is able to produce a product which beat products produced by other communities. A product can outperform other products when the products have characteristics better than rival products at the same price or more lace

Fernandez Pablo, 2003, the divide valuation method companies into (1) a method based on the balance of the method of assessment at book value, the book value adjusted, the value liquidize and value substantially (2) a method based on the income statement that is a multiple or a relative valuation, PER, sales and Price / EBITDA. (3) a method which is based on the goodwill that classical methods, methods of the European Union, methods of expert akuntans in the European Union, the indirect method, the method Anglo Saxon or direct method, method of annual profit purchase and methods of risk-bearing and risk free rate (Russo and Fouts, 1997). In this section, we discuss physical assets and technologies, human resources and organizational capabilities, and intangible resources in turn, arguing that industry context in general, and the growth within an industry in particular, moderate the influence of social performance on economic performance. Performance measurement mechanism that is often used is the financial ratio to look at the effectiveness and efficiency of capital use and according Ruru (1995: 15) ROI (Return on Investment) is one of the effective management tool in evaluating the business value and at the same time the ratio of performancemanagement. Ratio Return on assets (ROA) and return on equity (ROE), both the instruments give different results, because the ROA reflect the efficiency and effectiveness of the use of total assets / wealth of the company to generate profits, while ROE illustrate the ability to create profits by using the entire capital own. 
Based on the results of these underlying differences in doing research are that separates the measuring instrument ROA and ROE in researching the company's performance of the company.

Kuncoro (2002) mentions that small businesses and home businesses in Indonesia have played an important role in absorbing L16abor force increase the number of business units and support household income. Baronet and St-pierre (2004), states a positive relationship, Several Researchers have looked at the relation between innovation and performance and its impact on competitive advantage (Verhees and Meulenberg, 2004) Some researchers concentrated on the relationship between innovation and performance and its impact on competitive advantage

\section{Methodology}

Conceptual framework: Jayapura is one of the cities in the province of Papua, which has distinctive characteristics compared to other cities in Indonesia, cultural diversity and natural resource potential to encourage all parties to visit the city. This potential needs to be introduced to a wide range of diversity of products that can be produced both goods and services which have a value of its own. To realize these expectations, it takes a creative business through populist effort as small businesses that can meet the needs of the community. This study tried to examine the effect of mutual relationship between internal factors consisting of: human resource management, production, marketing, working capital, and organizations, as well as external factors consist of government policy and a competitor to the financial performance in enhancing the competitiveness of Small and Medium Enterprises in the city of Jayapura. And Images of conceptual framework are as follows:

Figure 1: Conceptual Framework

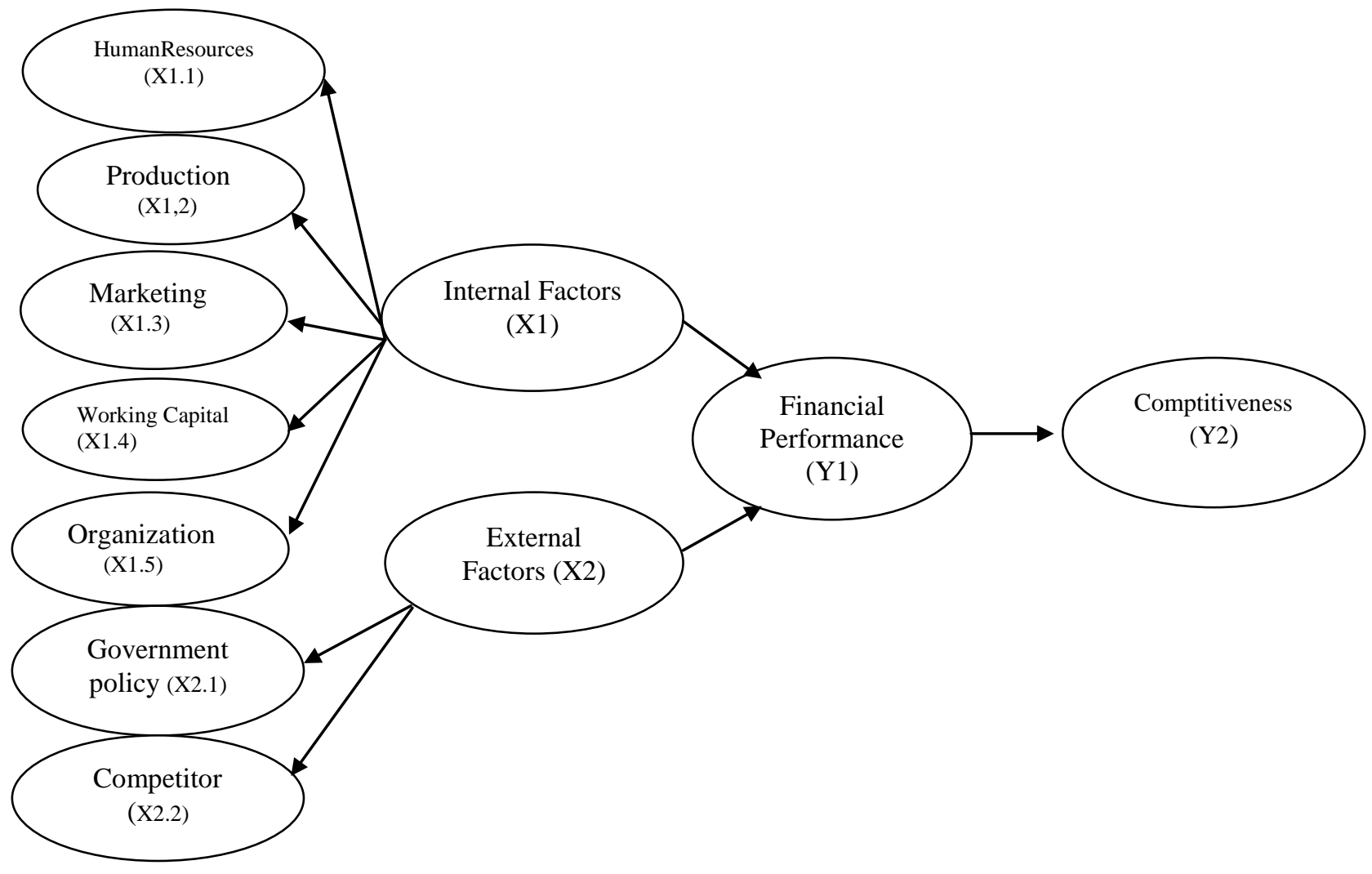

Based on the research described in the conceptual framework, then the following will formulate hypotheses: 
- Internal factors comprising for human resource management, production, marketing, working capital, and organizational influence on the financial performance of Small and Medium Enterprises in Jayapura city.

- Internal factors comprising for human resource management, production, marketing working capital, and organizational impact on the competitiveness of Small and Medium Enterprises in Jayapura city.

- External factors that consists of government policies and the effect on competitors the financial performance of small and medium-sized enterprises in Jayapura city.

- External factors that consists of government policies and the effect on competitors the competitiveness of small and medium enterprises in Jayapura city.

- Financial performance effect on the competitiveness of small and medium enterprises in city.

\section{Results}

Hypothesis testing

Table 1: Critical Ratio and Probability

\begin{tabular}{|c|c|c|c|c|c|c|c|}
\hline \multicolumn{8}{|c|}{ Regression Weights } \\
\hline & & & Estimate & S.E. & C.R. & $\mathbf{P}$ & Label \\
\hline KK & $<--$ & Organi & $-0,011$ & 0,079 & $-0,136$ & 0,892 & par-20 \\
\hline KK & $<--$ & Pmh & $-0,125$ & 0,062 & -2 & 0,046 & par-21 \\
\hline KK & $<--$ & Psg & 0,14 & 0,092 & 1,514 & 0,130 & par-22 \\
\hline KK & $<--$ & Prod & 0,138 & 0,064 & 2,147 & 0,032 & par-24 \\
\hline KK & $<--$ & Uang & 2,336 & 0,246 & 9,492 & 0,000 & par-25 \\
\hline KK & $<--$ & Pasar & 0,035 & 0,068 & 0,506 & 0,613 & par-26 \\
\hline KK & $<--$ & Msdm & 0,084 & 0,067 & 1,253 & 0,210 & par-27 \\
\hline Ds & $<--$ & Pasar & 0,184 & 0,075 & 2,449 & 0,014 & par-14 \\
\hline Ds & $<--$ & Prod & 0,393 & 0,074 & 5,326 & 0,000 & par-15 \\
\hline Ds & $<--$ & Msdm & 0,298 & 0,074 & 4,006 & 0,000 & par-16 \\
\hline Ds & $<--$ & Organi & $-0,234$ & 0,087 & $-2,697$ & 0,007 & par-17 \\
\hline Ds & $<--$ & $\mathrm{Pmh}$ & $-0,24$ & 0,069 & $-3,468$ & 0,001 & par-18 \\
\hline Ds & $<--$ & Psg & 0,514 & 0,109 & 4,73 & 0,000 & par-19 \\
\hline Ds & $<--$ & Uang & 0,06 & 0,314 & 0,191 & 0,849 & par-23 \\
\hline Ds & $<--$ & $\mathrm{KP}$ & 0,244 & 0,069 & 3,509 & 0,000 & par-28 \\
\hline Po & $<--$ & Organi & 1 & & & & \\
\hline $\mathrm{Rk}$ & $<--$ & Organi & 0,833 & 0,077 & 10,755 & 0,000 & par-1 \\
\hline Bo & $<--$ & Organi & 0,711 & 0,073 & 9,671 & 0,000 & par-2 \\
\hline $\mathrm{Kk}$ & $<--$ & Msdm & 1 & & & & \\
\hline $\mathrm{Ku}$ & $<--$ & Msdm & 0,843 & 0,052 & 16,226 & 0,000 & par-3 \\
\hline Hka & $<--$ & Msdm & 0,815 & 0,052 & 15,695 & 0,000 & par-4 \\
\hline $\mathrm{Se}$ & $<--$ & Prod & 1 & & & & \\
\hline $\mathrm{Tp}$ & $<--$ & Prod & 0,8 & 0,064 & 12,479 & 0,000 & par-5 \\
\hline $\mathrm{Bb}$ & $<--$ & Prod & 0,834 & 0,061 & 13,752 & 0,000 & par-6 \\
\hline $\mathrm{Pt}$ & $<--$ & Pasar & 1 & & & & \\
\hline $\mathrm{Pl}$ & $<--$ & Pasar & 0,971 & 0,059 & 16,499 & 0,000 & par-7 \\
\hline $\operatorname{Pr}$ & $<--$ & Pasar & 0,933 & 0,055 & 17,033 & 0,000 & par-8 \\
\hline $\mathrm{Pp}$ & $<--$ & Pmh & 1 & & & & \\
\hline $\mathrm{Bt}$ & $<--$ & Pmh & 0,913 & 0,069 & 13,287 & 0,000 & par-9 \\
\hline $\mathrm{Ri}$ & $<--$ & Pmh & 0,869 & 0,066 & 13,138 & 0,000 & par-10 \\
\hline Hmp & $<--$ & Psg & 1 & & & & \\
\hline Ipd & $<--$ & Psg & 1,101 & 0,111 & 9,901 & 0,000 & par-11 \\
\hline
\end{tabular}




\begin{tabular}{llllllll}
\hline Ipl & $<--$ & Psg & 1,272 & 0,128 & 9,938 & 0,000 & par-12 \\
$\mathrm{Kg}$ & $<--$ & Ds & 1 & & & & \\
$\mathrm{Rg}$ & $<--$ & Ds & 0,972 & 0,053 & 18,367 & 0,000 & par-13 \\
$\mathrm{Nr}$ & $<--$ & Ds & 0,915 & 0,052 & 17,665 & 0,000 & par-49 \\
\hline
\end{tabular}

Sumber: hasil hasil olahan data

Hypothesis testing is done by comparing the $t$ (proxy critical limit ratio) with $t$ table. Or look at a significant level. This section will test five hypotheses. The first hypothesis states that internal factors that consists of human resource management, production, marketing, working capital and organizational influence on the financial performance of Small and Medium Enterprises in the city of Jayapura result is:

Human resource management (X1.1) does not affect the performance small and medium Enterprises in Jayapura. Results of the analysis showed that $\mathrm{t}$ for 1,253 .To by 186 degrees of freedom and a significant level of $\alpha / 2$ or $5 \% / 2$ or 0.025 . Then $t$ table is 1.960 . Therefore $t(1.253<1.960)$, the hypothesis is not proven. This can be seen in the well at a rate (the probability or significance or error rate), which amounted to 0.210 (21\%). Production (X1.2) effect on the financial performance of furniture and printing of small businesses in the city of Jayapura. Results of the analysis showed that $t$ amounted to 2,147. For degrees of freedom for 186 and a significant level of $\alpha / 2$ or $5 \% / 2$ or 0.025 . Then $t$ table is 1.960 . Therefore $t(2,147>1,960)$, the hypothesis is accepted or proven. This can be seen in the well at a rate (the probability or significance or error rate), which amounted to 0.032 (3.2\%). Marketing (X1.3) effect on the financial performance of small businesses in the city of Jayapura. Results of the analysis showed that $t$ by 0506 . For degrees of freedom for 186 and a significant level of $\alpha / 2$ or $5 \% / 2$ or 0.025 . Then $t$ table is 1.960 . Therefore $t(0506<1960)$ then the hypothesis is not proven. This can be seen in the well at a rate (the probability or significance or error rate), which amounted to 0613 (61.3\%). Working capital (X1.4) effect on the financial performance of small businesses in the city of Jayapura. Results of the analysis showed that $t$ by 9492 . For degrees of freedom for 186 and a significant level of $\alpha / 2$ or $5 \% / 2$ or 0.025 . Then $t$ table is 1.960 . Therefore $t(9492>1960)$ then the hypothesis is accepted or proven. This can be seen in the well at a rate (the probability or significance or error rate) were $0.000(0 \%)$.

Organization (x1.5) effect on the financial performance of Small and Medium Enterprises in the city of Jayapura. Results of the analysis showed that $t$ at -0136 . For degrees of freedom for 186 and a significant level of $\alpha / 2$ or $5 \%$ / 2 or 0.025 . Then $t$ table is -1960 (testing the left side of the normal curve). Therefore $t$ ($0136>1960$ ) hypothesis is not proven. This can be seen in the well at a rate (the probability or significance or error rate), which amounted to 0892 (89.2\%). The second hypothesis states that internal factors that consists of human resource management, production, marketing, working capital, and organizational impact on the competitiveness of Small and Medium Enterprises in the city of Jayapura result is: Human resource management (X1.1) effect on the competitiveness of Small and Medium Enterprises in the city of Jayapura. Results of the analysis showed that $t$ by 4006. For degrees of freedom for 186 and a significant level of $\alpha / 2$ or $5 \%$ / 2 or 0.025 . Then $t$ table is 1.960 . Therefore $t(4006>1960)$ then the hypothesis is accepted or proven. This can be seen in the well at a rate (the probability or significance or error rate) were $0.000(0 \%)$. Production (X1.2) effect on the competitiveness of small and medium enterprises in the city of Jayapura. Results of the analysis showed that t by 5326. For degrees of freedom for 186 and a significant level of $\alpha / 2$ or $5 \%$ / 2 or 0.025 . Then $t$ table is 1.960 . Therefore $t(5,326>1,960)$ then the hypothesis is accepted or proven. This can be seen in the well at a rate (the probability or significance or error rate) were $0.000(0 \%)$. Marketing (X1.3) effect on the competitiveness of small and medium enterprises in Jayapura. Results of the analysis showed that $t$ by 2449 . For degrees of freedom for 186 and a significant level of $\alpha / 2$ or $5 \% / 2$ or 0.025 . Then $t$ table is 1.960 . Therefore $t(2,449>1,960)$ then the hypothesis is accepted or proven. It can be seen also on the rate (the probability or significance or error rate) that for 0014 (1.4\%).

Working capital (X1.4) effect on the competitiveness of Small and Medium Enterprises in the city of Jayapura. Results of the analysis showed that $t$ by 0191 . For degrees of freedom for 186 and a significant level of $\alpha / 2$ or $5 \%$ / 2 or 0.025 . Then $t$ table is 1.960 . Therefore $t(0191<1960)$ then the hypothesis is not proven. This can be seen in the well at a rate (the probability or significance or error rate), which amounted to 0849 $(84.9 \%)$. Organization (x1.5) effect on the competitiveness of small and medium in the city of Jayapura. 
Results of the analysis showed that $t$ at -2697. For degrees of freedom for 186 and a significant level of $\alpha / 2$ or $5 \%$ / 2 or 0.025 . Then $t$ table is -1960 (testing the left side of the normal curve). Therefore thitung ( -2697 $<-1960$ ) then the hypothesis is accepted or proven. This can be seen in the well at a rate (the probability or significance or error rate), which amounted to $0.007(0.7 \%)$. The third hypothesis states that external factors consisting of government policy and competitors affect the financial performance of Small and Medium Enterprises in the city of Jayapura result is: Government policies affect the financial performance of small and medium in the city of Jayapura. Results of the analysis showed that $t$ at -2000 For the degrees of freedom for 186 and a significant level of $\alpha / 2$ or $5 \%$ / 2 or 0.025 . Then $t$ table is -1960 (testing the left side of the normal curve). Therefore $t(-2000<-1960)$ then the hypothesis is accepted or proven. This can be seen in the well at a rate (the probability or significance or error rate), which amounted to $0.046(4.6 \%)$.

Competitors effect on the financial performance of furniture and printing of small businesses in the city of Jayapura. Results of the analysis showed that $\mathrm{t}$ amounted to 1,514. For degrees of freedom for 186 and a significant level of $\alpha / 2$ or $5 \% / 2$ or 0.025 . Then $t$ table is 1.960 . Therefore $t(1,514<1,960)$, the hypothesis is not proven. This can be seen in the well at a rate (the probability or significance or error rate), which amounted to 0.130 (13\%). Fourth hypothesis states that external factors consisting of government policy and competitors affect the competitiveness of Small and Medium Enterprises in the city of Jayapura result is: Government policies affect the competitiveness of Small and Medium Enterprises in the city of Jayapura. Results of the analysis showed that $t$ at -3468 . For degrees of freedom for 186 and a significant level of $\alpha / 2$ or $5 \% / 2$ or 0.025 . Then $t$ table is -1960 (testing the left side of the normal curve). Therefore $t(-3468<-$ 1960 ) then the hypothesis is accepted or proven. This can be seen in the well at a rate (the probability or significance or error rate) that of $0001(0.1 \%)$. Competitors effect on the competitiveness of Small and Medium Enterprises in the city of Jayapura. Results of the analysis showed that $t$ amounted to 4,730. For degrees of freedom for 186 and a significant level of $\alpha / 2$ or $5 \% / 2$ or 0.025 . Then $t$ table is 1.960 . Therefore $\mathrm{t}(4,730>1,960)$ then the hypothesis is accepted or proven. This can be seen in the well at a rate (the probability or significance or error rate) were $0.000(0 \%)$. Fifth hypothesis states that the financial performance factors affect the competitiveness of Small and Medium Enterprises in the city of Jayapura. Results of the analysis showed that $t$ by 3509. For degrees of freedom for 186 and a significant level of $\alpha / 2$ or $5 \% / 2$ or 0.025 . Then $t$ table is 1.960 . Therefore $t(3,509>1,960)$ then the hypothesis is accepted or proven. This can be seen in the well at a rate (the probability or significance or error rate) were $0.000(0 \%)$.

\section{Discussion}

\section{Effect of Internal Factors against Financial Performance}

Human resource management is measured using three indicators that employee commitment is a high awareness of employees to always work properly in accordance with the job description, the feasibility of wages that the fit between the remuneration given to the work load, as well as employee relations with superiors, namely harmonious relationship between employees with superiors at work. The results showed that human resource management has no effect on the financial performance of Small and Medium Enterprises in the city of Jayapura. Many arguments can be put forward to explain this. One is that in a small business, the quality of human resources is not really a thing that affects financial performance. Typically, for workers, many of whom have long been working. So that the commitment, wage and its relationship with the boss did not significantly affect the performance of keuangan. Argument second is that the management of human resources, in the short term, it will not have an impact on financial performance. Since the development of human resources in small business is not very developed. But in the long term human resource management will have an impact on competitiveness.

Production is measured by three indicators of the economic scale is the low idle on production equipment, production technology that is the desire of owners to adopt the technology in the production process, then the availability of raw materials is the availability of raw materials to support a smooth production process. The results showed that the production of an effect on the financial performance of Small and Medium Enterprises in the city of Jayapura, the production capability has a significant influence on business performance, better use of ROA and ROE. Companies that enter more financial distress as a result of weakening economic management rather than as a result of production distress. Kemampuan of 
demonstrating competence in managing the company's production activities ranging from purchasing and management of raw materials and auxiliary materials, preparation and maintenance of machinery and equipment, management during the process production to products produced production capability will directly affect financial performance. Since most small businesses based on consumer demand, the production capacity will be a direct impact on financial performance.

Marketing is measured by three indicators, namely product is compatibility between the qualities of the product provided the company with the quality that consumers expect, Place of ease in obtaining the product, and then the third indicator Price is the degree of correspondence between price and quality provided by the company's products. Based on these three indicators of the results showed that the marketing factor does not affect the financial performance of Small and Medium Enterprises in the city of Jayapura. The results showed that his path coefficient -0.166 with p-value 0.339 . Thus the hypothesis is rejected; partially marketing capabilities have a significant influence on the performance business. Berdasarkan observation of marketing capabilities and performance indicators of the business, then there are some possibilities that cause marketing capabilities partially no significant effect on business performance. First, success in marketing the results cannot be seen directly accounting profit in the same period. Promotional activity, sacrifice to ensure image and brand companies to consumers are examples of indicators relative profitability has not been able to produce directly. Second, the relative financial performance cannot measure the impact of marketing capabilities partially. ,

Working capital is measured by four indicators, namely the management of working capital is the amount of working capital divided by total assets, new investment, additional new investments on average per year, then the indicators third capital structure is debt divided by assets, and a fourth indicator composition of short-term debt is short-term debt divided by total debt. Based on the four indicators, the results showed that the working capital impact on the financial performance of small and medium enterprises in Jayapura. This result indicates that if the financial capacity of improving the business performance will also increase, and vice versa if the increasingly ineffective financial management of the business performance will decrease.

Organization is measured using three indicators that control the range of effective leadership is the ability to control their employees, then the learning organization that is the desire of organizations to always learn from failures, and the third indicator is the adoption of the company's organizational culture to the values of a quality oriented. The indicator is based on the results of the research showed that the organization has no effect on the financial performance of small and medium enterprises in the city of Jayapura. These results indicate that the range of control, organizational learning and organizational culture does not have an impact on financial performance. Small businesses basically just have a bit of control ranges for small and medium business coverage. Small and medium businesses also have an organizational culture that is not well developed so it does not impact on the financial performance directly. However affect the competitiveness of enterprises.

\section{Affect of Internal Factors againts Competitiveness}

Human resource management affect the competitiveness of small and medium enterprises in the city of Jayapura. Competitive advantage and performance can be achieved by combining the primary activities and support activities in a company (Porter, 1991: 36-37). Primary activities include the logistics of materials and finished products, praduk processing, marketing and sales, and services. Variables supporters include infrastructure, human resources, technology, and purchasing. Factors Human resource management, in the long run, will have an impact on competitiveness through quality work. Good quality of work will have an impact on the outcome of the work or the products that will improve the competitiveness of small businesses. Barney and Wright (1997), value, rareness, limitability and organization framework to examine the role of the human resources function plays in developing a sustainable competitive advantage. (Skeletons value, infrequency, limitations and organizations can determine the role of the function of human resources in building excellence besaing continuous). Some of the arguments supporting Politian results.

Production effect on the competitiveness of Small and Medium Enterprises in the city of Jayapura. Competence will take into account the production company to produce a wide range of products, including 
items that are specific and high quality, to build a reputation in the industry and lower operating costs, which are key factors for the success of the competition. So production will certainly increase the competitiveness of small businesses. Villalonga (1999), intangible (such as a particular technology, corporate culture) pay an effective role in sustaining a competitive advantage firms. (Asset cannot be seen (technology and corporate culture) will provide an effective role in the company's competitive advantage memeprtahankan) .Argument supports the findings.

Marketing affect the competitiveness of Small and Medium Enterprises in the city Jayapura. Pengembangan new products, and continuous improvement can quickly anticipate the market demands and satisfy customers, which in turn will affect the competitiveness perusahaan. Sepertiyang we know that the factors of competitive strategy and strategy marketing, as well as elements of the marketing mix are the factors of competitive advantage. Marketing capabilities will enhance the image and product innovation in the long term will have an impact on the competitiveness of enterprises.

Working capital does not affect the competitiveness of Small and Medium Enterprises in the city of Jayapura. This could be due to the small businesses; working capital factor is not the deciding factor for competitiveness. Most small businesses have a need for funding that is not much. So that no significant impact on working capital, new investments and financial structure of small businesses. This is one argument why capital has no impact on the competitiveness of enterprises. Control over the use of credit from small businesses is very low. Often long-term loans used to finance working capital and short-term loan used to finance investments.

Organization affect the competitiveness of small and medium in the city of Jayapura. The ability of the organization, in the long run will affect competitiveness. Regular and systematic organization that will enhance the competitiveness of small businesses.

\section{Effect External Factors Against Financial Performance}

The government's policy is measured by three indicators of regulation is the number of rules in favor of SMEs, and technical assistance that is often entrepreneurs receive technical assistance from the government, the third indicator is the frequent coaching and training entrepreneurs receive coaching and training of government. Based on these three indicators of the results showed that government policies affect the financial performance of Small and Medium Enterprises in the city of Jayapura. However it has a negative coefficient. This means that the increase in the role of the government will make the company's financial performance to decrease. The high role of government will make small businesses become lulled because too hopes on the government rather than on internal capabilities. If this condition occurs, the role of government in the form of assistance will degrade performance. O'connor (2004) Business Development Program, which direct federal contracts to small businesses and operated by socially and economically disadvantage individuals. (Business development programs carried out directly by the federal government for small businesses that is not economically beneficial).

Competitors were measured by three indicators of the intensity of local competition is the high competition faced by entrepreneurs in the city of Jayapura, the second indicator is the intensity of competition domestically is high competition faced by entrepreneurs between regions in Indonesia, then the indicators third is the barrier to entry of competitors in the high barriers to entry for competitors new to the industry. Based on the three indicators are the results showed that the competitor does not affect the financial performance of small businesses in the city of Jayapura? Competitors for small businesses in the short term will not affect existing financial performance. This is due to the small business units each have a different consumer and capabilities are relatively the same so that incoming competitors will not affect financial performance.

Effect of External Factors against Competitiveness: Government policies affect the competitiveness of small businesses and percetkan furniture in the city of Jayapura. However, the coefficient is negative. This means that the government's role will increase the competitiveness of the company to decrease. The results showed that the role of governments will make small businesses become lulled because too hopes on the 
government rather than on internal capabilities. If this condition occurs, the role of government in the form of assistance will reduce the competitiveness. Competitors effect on the competitiveness of Small and Medium Enterprises in the city of Jayapura. In the long term, the entry of competitors will have an impact on the competitiveness of enterprises. This is consistent with the model of Porter's competitive advantage; it states that the entry of new competitors and the low barriers to entry into the industry will have an impact on competitive advantage or competitiveness.

Effect of Financial Performance against Competitiveness: Factors financial performance is measured by four indicators, namely ROA, ROE, profit margin and current ratio while competitiveness factors ditukur with cognitive measures are competency-led individually in managing the business, then the second indicator normative that the ability of the leadership in managing the organization well, the indicators third namely regulative competitiveness is the ability of the leadership to try to determine the position as the best company in the industry level. Based on these indicators the results showed that its effect on the competitiveness of Small and Medium Enterprises in the city of Jayapura. High financial performance will improve business competitiveness. This means that businesses that have high performance will make an effort would be easier to survive and exist. He will also be able to survive and thrive while many competitors are entering. High financial performance makes the company financially sound and thus will improve the competitiveness of enterprises.

\section{Conclusion}

A. Internal factors of human resource management has no effect on the financial performance of furniture and printing of small businesses in the city of Jayapura. Many arguments can be put forward to explain this. One is that in a small business, the quality of human resources is not really a thing that affects financial performance. Typically, for workers, many of whom have long been working. So the commitment, wage and its relationship with the boss did not significantly affect the financial performance. However berdasrkan penilitian results indicate that human resource management affect the competitiveness of small businesses in the city of Jayapura. Management of human resources, in the long run, will have an impact on competitiveness through quality work. Good quality of work will have an impact on the outcome of the work or the products that will improve the competitiveness of Small and Medium Enterprises. Internal factors of production affect the financial performance and production factors also affect the competitiveness of Small and Medium Enterprises in the internal Jayapura. Factor city marketing based on research results indicate that marketing factors do not affect the financial performance of Small and Medium Enterprises in the city of Jayapura. Based on the observations of the marketing and indicator, then there are several possible causes partial marketing factors had no significant effect on the financial performance. First, success in marketing the results cannot be seen directly accounting profit in the same period. Promotional activity, sacrifice to ensure image and brand companies to consumers are examples of indicators relative profitability has not been able to produce directly. Second, the relative financial performance cannot measure the impact of marketing capabilities partially. And the results showed that the marketing effect on the competitiveness of Small and Medium Enterprises in the city of Jayapura. Marketing capabilities will enhance the image and product innovation in the long term will have an impact on the competitiveness of the internal perusahaan. Factor working capital based on the results of the study showed that working capital effect on the financial performance of Small and Medium Enterprises in the city of Jayapura. Although working capital effect on financial performance, but the results showed that working capital had no effect on the competitiveness of Small and Medium Enterprises in the city of Jayapura. This could be due to the small businesses; working capital factor is not the deciding factor for competitiveness.

Most small businesses have a need for funding that is not much. So that no significant impact on working capital management, new investment and financial structure of the Small and Medium Enterprises. Internal factors Based Organization research results show that the organization has no effect on the financial performance of Small and Medium Enterprises in the city of Jayapura. These results indicate that the range of control, organizational learning and organizational culture does not have an impact on financial performance. This is because the Small and Medium Enterprises are basically only has a range of control that a little bit because of the small business coverage. Small and Medium Enterprises also has an organizational culture that is not well developed so it does not impact on the financial performance directly, but affects the 
competitiveness perusahaan. Research result shows that the organization affect the competitiveness of Small and Medium Enterprises in the city of Jayapura. The ability of the organization, in the long run will have an impact on competitiveness. Regular and systematic organization that will enhance the competitiveness of Small and Medium Enterprises.

B. Esternal Factor policy is based on the results of the research show that government policies affect the financial performance of Small and Medium Enterprises in the city of Jayapura. However it has a negative coefficient. This means that the increase in the role of the government will make the company's financial performance to decrease. The high role of government will make small businesses become lulled because too hopes on the government rather than on internal capabilities. If this condition occurs, the role of government in the form of assistance will degrade performance. The results showed that government policies affect the competitiveness of Small and Medium Enterprises in the city of Jayapura. However, the coefficient is negative. This means that the government's role will increase the competitiveness of the company to decrease. The results showed that the role of governments will make small businesses become lulled because too hopes on the government rather than on internal capabilities. If this condition occurs, the role of government in the form of assistance will reduce the power of the External saying. Factor competitors based on three indicators were the results showed that the competitor does not affect the financial performance of Small and Medium Enterprises in the city of Jayapura. Competitors for small businesses in the short term will not affect existing financial performance. This is due to the small business units each have a different consumer and capabilities are relatively the same so that incoming competitors will not affect the performance of keuangan. Result shows that competitors affect the competitiveness of Small and Medium Enterprises in the city of Jayapura. In the long term, the entry of competitors will have an impact on the competitiveness of enterprises. This is consistent with the model of Porter's competitive advantage; it states that the entry of new competitors and the low barriers to entry into the industry will have an impact on competitive advantage or competitiveness.

C. Factors financial performance based on the results of the study showed that the company's effect on the competitiveness of Small and Medium Enterprises in the city of Jayapura. High financial performance will improve business competitiveness. This means that businesses that have high performance will make an effort would be easier to survive and exist. He will also be able to survive and thrive while many competitors are entering. High financial performance makes the company financially sound and thus will improve the competitiveness of enterprises.

\section{Suggestions}

A. Expected Jayapura city government is able to do with the growth of new entrepreneurs toward the target offenders who nurtured and developed, so that the growth of new entrepreneurs will be able to add to the workforce and will reduce pengangguran. Program aid in the form of training provided Jayapura city government should be planned carefully consider the needs training in the field without hunting for quantity but rather the quality of the training it sendiri. Diharapkan Jayapura city government also makes it easy for small and medium enterprises in obtaining capital structure is used so that the performance of small businesses in the city of Jayapura will be superior and able to thrive, because it has a capital structure stronger.

B. Small and Medium Businesses must constantly improve their own management capabilities, along with the growth of its business, should mature in planning Roling industry positions for the avoidance of doubt, it should be good at adapting to suit the various stages of their business growth.

C. Once proven based on the results of internal and external factors that have an influence on the financial performance of small and medium enterprises should pay more attention to these factors on the financial performance. For factors that negatively influence government policy factors in order to be studied further, thus avoiding the impact on the company.

\section{References}

Villalonga, B. (1999). Intangible Resources and Sustainability of Competitive Advantage, Strategy and Organization Anderson Graduate School of Management University of California, Los Angeles, PP 139. 
Baronet, J. \& St-Pierre, G. (2004). Innovation in SMEs: Who? What Kind? With What Effect? Preliminary Result of An Exploratory Study, University de Sherbrooke, Canada, 1-12

Daulay, P., Hotmatua, L. \& Lyanto, M. (2001). The ability to Compete is measured by the cost of Hotmatua, Daulay, and Mulyanto, 2001.

Barney, J. B. \& Wright, P. M. (1997). On Becoming a Strategic partner: The Role of Human Resources in Gaining Competitive Advantage, Working Paper, pp. 1-26.

O'Connor, J. (2004). Significance of Government Procurement to Small Business, 1-32.

Kuncoro, M. (2002b). A Quest for Industrial Districts: An Empirical Study of Manufacturing Industries in Java." Paper presented at a workshop Economic Growth and Institutional Change in Indonesia during the 19th and 20th Centuries, Amsterdam February 25 to 26.

Kwon, S. C. \& Shin, T. S. (2003). Cointegration and Causality between Macroeconomic Variables and Stock Market Return.

Porter, M. E. (1991). America's green strategy. Scientific American, 264(4), 168.

Pakpahan as in Daulay, Hotmatua and mouth lyanto (2001: 80), the ability to Compete is measured by the cost of Hotmatua, Daulay, and Mulyanto, 2001.

Russo, K. \& Fouts, P. A. (1997). A Resource-Based Perspective on Corporate Environmental Performance and Profitability. Academy of Management Journal, 40(3), 534-559.

Ruru, B. (1995). SOE policy direction Facing Era of AFTA in 2003 and EPEC 2020. Magazine of Management and Entrepreneurship, 9, 34-35. 55

Sasono, A. (2002). Effects of Globalization on the Economy of Indonesia (Small Business Perspective Menengah FE Airlangga University, June 10, 2002, Surabaya.

Scarborough, N. M., Thomas, D. \& Zimmerer, W. (1993). Effective Small Business Management. New York: Macmillan Publishing Company.

Stifung, S. R. S. (1991). Research Training Needs for Small Industries in Bandung. Un-published Research Report. Publisher ubuntu, Bandung.

Verhees, F. J. H. M. \& Meulemberg, M. T. G. (2004). Market orientation, innovativeness, product innovation, and performance in small firm. Small Business Management, 42, 134-154. 